\title{
The Thyroid Gland Is a Major Source of Circulating $T_{3}$ in the Rat
}

\author{
Jean-Pierre Chanoine, Lewis E. Braverman, Alan P. Farwell, Marjorie Safran, Sharon Alex, \\ Susan Dubord, and Jack L. Leonard \\ Departments of Nuclear Medicine, Physiology, and Medicine, University of Massachusetts Medical Center, \\ Worcester, Massachusetts 01655
}

\begin{abstract}
In rats, the respective contribution of the thyroid and peripheral tissues to the pool of $\mathrm{T}_{3}$ remains unclear. Most, if not all, of the circulating $T_{3}$ produced by extrathyroidal sources is generated by $5^{\prime}$-deiodination of $T_{4}$, catalyzed by the selenoenzyme, type I iodothyronine 5'-deiodinase (5'D-I). 5'D-I in the liver and kidney is almost completely lost in selenium deficiency, resulting in a marked decrease in $T_{4}$ deiodination and an increase in circulating $T_{4}$ levels. Surprisingly, circulating $T_{3}$ levels are only marginally decreased by selenium deficiency. In this study, we used selenium deficiency and thyroidectomy to determine the relative contribution of thyroidal and extrathyroidal sources to the total body pool of $T_{3}$. Despite maintaining normal serum $T_{4}$ concentrations in thyroidectomized rats by $T_{4}$ replacement, serum $T_{3}$ concentrations remained 55\% lower than those seen in intact rats. In intact rats, restricting selenium intake had no effect on circulating $T_{3}$ concentrations. Decreasing $5 \mathrm{D}-\mathrm{I}$ activity in the liver and kidney by $>90 \%$ by restricting selenium intake resulted in a further $20 \%$ decrease in serum $T_{3}$ concentrations in the thyroidectomized, $T_{4}$ replaced rats, suggesting that peripheral $T_{4}$ to $T_{3}$ conversion in these tissues generates approximately $20 \%$ of the circulating $T_{3}$ concentrations. While dietary selenium restriction markedly decreased intrahepatic selenium content ( $>95 \%)$, intrathyroidal selenium content decreased by only $27 \%$. Further, thyroid 5'D-I activity actually increased $25 \%$ in the selenium deficient rats, suggesting the continued synthesis of this selenoenzyme over selenoproteins in other tissues in selenium deficiency. These data demonstrate that the thyroid is the major source of $T_{3}$ in the rat and suggest that intrathyroidal $T_{4}$ to $T_{3}$ conversion may account for most of the $\mathrm{T}_{3}$ released by the thyroid. (J. Clin. Invest. 1993. 91:2709-2713.) Key words: deiodination • selenium $\bullet$ thyroid $\cdot$ hormone metabolism $\cdot T_{4}$ to $T_{3}$ conversion
\end{abstract}

\section{Introduction}

In mammals, the relative contribution of thyroidal and extrathyroidal sources to the total body pool of the metabolically

Part of this work has been presented as an abstract at the 20th meeting of the European Thyroid Association, Dublin, Ireland, 20-25 June 1992. Address reprint requests to Dr. Jack L. Leonard, Department of Nuclear Medicine, University of Massachusetts Medical School, 55 Lake Avenue North, Worcester, MA 01655.

Received for publication 23 October 1992 and in revised form 8 January 1993

J. Clin. Invest.

(c) The American Society for Clinical Investigation, Inc. 0021-9738/93/06/2709/05 \$2.00

Volume 91, June 1993, 2709-2713 active iodothyronine, 3,5,3'-triiodothyronine $\left(\mathrm{T}_{3}\right)$, is unclear. $T_{3}$ can be derived from conversion of the prohormone thyroxine $\left(T_{4}\right)$ by outer ring $\left(5^{\prime}-\right)$ deiodination in the peripheral tissues, by $T_{4}$ to $T_{3}$ conversion within the thyroid gland, and by direct secretion of de novo synthesized thyroidal $T_{3}$. Estimates of the contribution of extrathyroidal $\mathrm{T}_{4}$ to $\mathrm{T}_{3}$ conversion to the total $\mathrm{T}_{3}$ pool vary from $20 \%$ to $100 \%$ in the rat (1-3) and the thyroid accounts for the remainder of the $T_{3}$ produced daily. Laurberg used in situ thyroid perfusion to directly examine the contribution of the thyroid to the $T_{3}$ pool and reported that intrathyroidal $T_{4}$ to $T_{3}$ conversion accounted for a considerable portion of the $T_{3}$ secreted from the dog thyroid $(4,5)$. Thus, both extrathyroidal and intrathyroidal $T_{4}$ to $T_{3}$ conversion appear to participate in the daily production of $T_{3}$.

$T_{4}$ to $T_{3}$ conversion is catalyzed by the enzyme, iodothyronine 5 '-deiodinase. Two isozymes of iodothyronine 5 '-deiodinase have been identified. The most abundant form, type I iodothyronine $5^{\prime}$-deiodinase ( $5 \mathrm{D}-\mathrm{I}$ ), is found in liver, kidney, and thyroid (6) and contains the rare amino acid selenocysteine (7-9). Tissue content of 5D-I in the liver and kidney is proportional to selenium intake (10). The other isozyme, type II iodothyronine 5 'deiodinase ( $5^{\prime} \mathrm{D}$-II), is abundant in the brain, pituitary, and brown adipose tissue and does not contain selenium $(11,12) . T_{3}$ generated by $5^{\prime} \mathrm{D}-\mathrm{I}$ is released into the general circulation, while the majority of the $T_{3}$ produced by 5'D-II remains with the cell. The ability to manipulate 5'D-I levels by altering the dietary intake of selenium provides the means to examine the contribution of 5 D-I to total $\mathrm{T}_{3}$ production. Selenium deficiency leads to an almost complete loss of 5'D-I in the liver and kidney and a $40-50 \%$ increase in the serum $\mathrm{T}_{4}$ concentration $(10,12-14)$. This increment in circulating $\mathrm{T}_{4}$ is completely accounted for by the prolonged metabolic half-life of the iodothyronine due to the loss of 5'D-I (14). Paradoxically, serum $T_{3}$ concentrations are not reciprocally affected and decrease by no more than $20 \%$, if at all (12-14). While serum $T_{3}$ concentrations are marginally depressed by selenium deficiency, circulating $T_{3}$ sulfate concentrations increase nearly twofold $(12,14)$. Serum TSH levels remain near normal despite the elevated circulating $\mathrm{T}_{4}$ in the selenium-deficient animal (12-14). Thus, despite the marked decrease in hepatic and renal $T_{4}$ to $T_{3}$ conversion in the absence of selenium, other sources of $T_{3}$ appear to be made available in animals lacking 5'D-I.

There are several possibilities to account for the discordance between the near complete loss of 5'D-I and the marginal fall in circulating $T_{3}$ observed in selenium deficiency. They include $(a)$ diminished $\mathrm{T}_{3}$ clearance, $(b)$ increased thyroidal $T_{3}$ secretion, and/or $(c)$ enhanced recovery of $T_{3}$ from sulfo-conjugates released into the gut in the enterohepatic cycle. Previous work has shown that $\mathrm{T}_{3}$ clearance is only marginally decreased by selenium deficiency and that the $20-25 \%$ increase in the metabolic half-life of this iodothyronine is insuffi- 
cient to maintain the steady-state levels of $T_{3}$ observed in serum (14). The contribution of the thyroid to the $T_{3}$ pool in the selenium-deficient rat remains to be determined. Likewise, the contribution of enterohepatic recycling of $\mathrm{T}_{3}$ or its conjugates to the circulating $\mathrm{T}_{3}$ pool is unclear.

In this study, we determined the source( $(s)$ of circulating $T_{3}$ in selenium-deficient rats. The data show that the thyroid gland serves as a major source of circulating $T_{3}$ in the rat and suggest that intrathyroidal $T_{4}$ to $T_{3}$ conversion accounts for much of the $T_{3}$ secreted by the thyroid.

\section{Methods}

Animals and reagents. Weanling male Sprague-Dawley rats $(40-50 \mathrm{~g})$ supplied by Charles River Laboratories (Wilmington, MA) were used in all experiments. The study was approved by the Animal Research Committee and complies with the institutional assurance certificate of the University of Massachusetts Medical Center. Rats were fed a torula yeast based semisynthetic diet ( Teklad Premier Laboratory Diets, Madison, WI) for $5 \mathrm{wk}$. The selenium-deficient diet (TD 86298) contains less than $16 \mu \mathrm{g} / \mathrm{kg}$ selenium and the selenium-replete diet (TD 91259) is the same base diet supplemented with $200 \mu \mathrm{g} / \mathrm{kg}$ selenium as $\mathrm{Na}_{2} \mathrm{SeO}_{3}$. Rats were housed in stainless steel cages, and distilled water was available ad lib. Body weight (BW) ${ }^{1}$ was monitored biweekly.

Analytical procedures and hormone assays. In all experiments, animals were killed by decapitation and exsanguinated, except where noted. Liver was homogenized in $4 \mathrm{vol}(\mathrm{wt} / \mathrm{vol})$ of $20 \mathrm{mM}$ potassium phosphate buffer ( $\mathrm{pH} 7.4), 150 \mathrm{mM} \mathrm{NaCl}$, and in $4 \mathrm{vol}$ ( wt/ vol ) of 250 $\mathrm{mM}$ sucrose, $20 \mathrm{mM}$ Hepes buffer ( $\mathrm{pH}$ 7.0), 1 mM EDTA, and $1 \mathrm{mM}$ DTT and stored at $-20^{\circ} \mathrm{C}$ for determination of glutathione peroxidase activity (GPx) and 5'D-I activity, respectively. Thyroid glands were weighed and homogenized in $800 \mu \mathrm{l}$ of $250 \mathrm{mM}$ sucrose, $20 \mathrm{mM}$ Hepes buffer ( $\mathrm{pH} 7.0$ ), $1 \mathrm{mM}$ EDTA, and $1 \mathrm{mM}$ DTT for determination of 5'D-I activity.

The degree of selenium deficiency in the rats was determined by the decrease in hepatic GPx activity. GPx activity was determined from the oxidation of NADPH in the presence of $0.35 \mathrm{mM} t$-butyl hydroperoxide monitored spectrophotometrically at $340 \mathrm{~nm}$ (15). Samples were run in duplicate and results were expressed as nmol NADPH oxidized/ min per mg protein. Hepatic GPx activities in intact, selenium-replete and thyroidectomized, $\mathrm{T}_{4}$ replaced, selenium-replete rats were $598 \pm 58$ $\mathrm{nmol}$ NADPH oxidized/min per mg protein $(n=9)$ and $906 \pm 53 \mathrm{nmol}$ NADPH oxidized/min per mg protein $(n=12)$, respectively.

Type I iodothyronine 5 '-deiodinase activity was determined by the release of radioiodide from $10 \mu \mathrm{M}\left[{ }^{125} \mathrm{I}_{\mathrm{r}} \mathrm{rT}_{3}\right.$ in the presence of $20 \mathrm{mM}$ DTT (5'D-I) (16). Samples were run in duplicate and results were expressed as units $/ \mathrm{mg}$ protein; 1 unit of $5^{\prime} \mathrm{D}$-I enzyme activity represents the release of $1 \mathrm{pmol}$ radioiodine $/$ min per $\mathrm{mg}$ protein at $37^{\circ} \mathrm{C}$. Hepatic type I iodothyronine 5'-deiodinase activities in intact, selenium-replete and thyroidectomized, $\mathrm{T}_{\mathbf{4}}$ replaced, selenium-replete rats were $224 \pm 15 \mathrm{U} / \mathrm{mg}$ protein $(n=12)$ and $114 \pm 8 \mathrm{U} / \mathrm{mg}$ protein $(n$ $=9$ ), respectively.

Serum TSH was measured in duplicate by RIA using materials obtained from the National Pituitary Agency, National Institutes of Health (Bethesda, MD). Serum $T_{4}$ and $T_{3}$ concentrations were determined in duplicate by species-adapted specific RIAs.

Selenium was quantified by measuring the $162 \mathrm{KeV}$ gamma ray produced during the decay of radioactive ${ }^{77} \mathrm{mSe}$ after irradiation of the sample at a neutron flux. The sensitivity was $0.05 \mathrm{ppm}$ (Research Reactor Facility, University of Missouri-Columbia, Columbia, MO) (17).

Protein was measured by the method of Bradford (18).

1. Abbreviations used in this paper: BW, body weight; GPx, glutathione peroxidase activity.

\section{Experimental procedures}

Effect of altered selenium intake on serum $\mathrm{T}_{4}, \mathrm{~T}_{3}$, and TSH concentrations in $\mathrm{T}_{4}$ replaced, thyroidectomized rats. 35 rats ( 22 selenium supplemented and 13 selenium deficient) were used in this experiment. 3 wk before being killed, 12 selenium-supplemented and 6 selenium-deficient rats were anesthetized using $7 \mathrm{mg}$ ketamine and $0.6 \mathrm{mg}$ xylazine $/ 100 \mathrm{~g} \mathrm{BW}$ and the thyroid glands removed. $\mathrm{T}_{4}$ replacement was begun one day after thyroidectomy by daily intraperitoneal injections of $\mathrm{T}_{4}(1.1 \mu \mathrm{g} / 100 \mathrm{~g} \mathrm{BW})$ for $2 \mathrm{wk}$. For the final $7 \mathrm{~d}$ of the experiment, serum $\mathrm{T}_{4}$ concentrations were maintained at euthyroid levels by the use of an osmotic minipump (Alzet 2001; Alza Corp., Palo Alto, CA) calculated to deliver $\mathrm{T}_{4}$ at a rate of $1.1 \mu \mathrm{g} / 100 \mathrm{~g} \mathrm{BW}$ per day. $\mathrm{T}_{4}$ (Sigma Chemical Co., St. Louis, MO) used for hormone replacement was $>99.7 \%$ pure as measured by HPLC.

Effect of selenium deficiency on the selenium content and 5'D-I activity in the thyroid gland. 15 rats ( 8 selenium supplemented, and 7 selenium deficient) were anesthetized as described above and perfused through the aorta with $40 \mathrm{ml}$ of ice-cold saline. The exsanguinated thyroid gland and liver were removed and frozen at $-70^{\circ} \mathrm{C}$ for subsequent determination of selenium content by neutron activation analysis. In a parallel experiment, thyroidal and liver 5'D-I activities were determined in 10 selenium-supplemented and 10 selenium-deficient rats.

Effects of selenium deficiency on intrathyroidal metabolism of ${ }^{131} I$. Intrathyroidal metabolism of ${ }^{131} \mathrm{I}$ was determined in groups of 5 rats ( 5 selenium supplemented and 5 selenium deficient ). Animals were killed $2 \mathrm{~h}$ after the intraperitoneal injection of $10 \mu \mathrm{C} \mathrm{Na}{ }^{131} \mathrm{I}(16.2 \mathrm{Ci} / \mu \mathrm{g})$. Thyroid glands were then dissected free of connective tissue and homogenized in $500 \mu \mathrm{l}$ of sodium barbital buffer ( $\mathrm{pH} 8.6$ ) containing 20 $\mathrm{mM}$ methimazole and $4 \mathrm{mM}$ KI. The percent uptake of radioiodide and the distribution of the ${ }^{131} \mathrm{I}$ between MIT, DIT, $T_{3}$, and $T_{4}$ was determined by descending paper chromatography after pronase digestion of thyroidal homogenates according to Vagenakis et al. (19).

\section{Statistics}

The results are presented as mean \pm SE. Statistical significance $(P$ $<0.05$ ) was determined using the Student's $t$ test for unpaired values.

\section{Results}

Effects of selenium status on serum $T_{4}, T_{3}$, and TSH concentrations in $T_{4}$ replaced, thyroidectomized rats. During the 5-wk experimental period, body weights increased from 55 to $330 \mathrm{~g}$ in the euthyroid rats (intact) $(n=17)$ and from 55 to $289 \mathrm{~g}$ in the thyroidectomized rats replaced with $\mathrm{T}_{4}\left(\mathrm{~T}_{4}\right.$ replaced) ( $n$ $=18$ ), indicating that hormone replacement was almost complete in the thyroidectomized animals. No differences in growth were observed between the selenium-deficient and selenium-supplemented rats. Selenium deficiency resulted in a 97\% decrease in hepatic GPx activity and a parallel $93 \%$ decrease in hepatic $5^{\prime} \mathrm{D}-\mathrm{I}$ activity in both the intact and $\mathrm{T}_{4}$-replaced rats indicating that the animals were selenium deficient. As shown in Fig. 1, in selenium-supplemented rats, serum $T_{4}$ concentrations were similar in the intact and $\mathrm{T}_{4}$ replaced groups $(A)$. Selenium deficiency resulted in the expected increase in the serum $\mathrm{T}_{4}$ concentrations in both the intact and $\mathrm{T}_{4}$ replaced groups $(P<0.05, A$ vs. $B)$.

Although the serum $\mathrm{T}_{4}$ concentrations were identical in the selenium-supplemented intact and $T_{4}$ replaced rats, serum $T_{3}$ concentrations were not normalized and $\mathrm{T}_{3}$ concentrations in the $\mathrm{T}_{4}$ replaced rats remained $55 \%$ lower than those in the intact group (Fig. $1 \mathrm{C}$ ). Selenium deficiency did not significantly affect serum $\mathrm{T}_{3}$ values in the intact rats $(1.23 \mathrm{nM} \pm 0.14$ vs. $1.11 \pm 0.10$, selenium-supplemented vs. selenium-deficient 

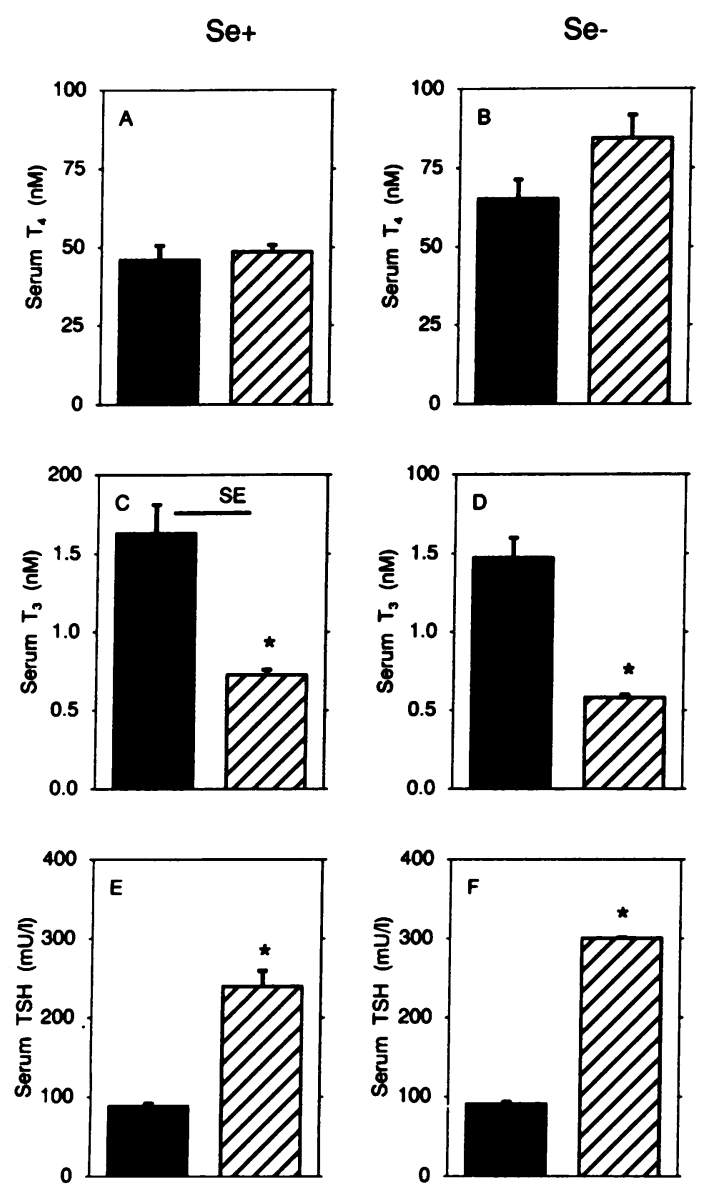

Intact

Figure 1. Effect of selenium and thyroidectomy on serum concentrations of $\mathrm{T}_{4}, \mathrm{~T}_{3}$, and TSH in the rat. Rats were fed a defined diet, thyroidectomized, and replaced with $\mathrm{T}_{4}$ as described in Experimental procedures. Blood was obtained at the time of killing and analyzed for $T_{4}, T_{3}$, and TSH. Intact, nonthyroidectomized rats; $T_{4}$ replaced, rats thyroidectomized and replaced with exogenous $T_{4}$. ${ }^{*} P<0.05$.

rats, respectively) but decreased the serum $T_{3}$ concentrations by $20 \%$ in the $\mathrm{T}_{4}$ replaced group $(C$ and $D)(0.55 \pm 0.03 \mathrm{nM}$ vs. $0.44 \pm 0.02 \mathrm{nM}, P<0.05$ selenium-supplemented vs. seleniumdeficient rats, respectively).

In both selenium-supplemented and selenium-deficient thyroidectomized rats, $T_{4}$ replacement did not normalize the serum TSH concentrations, and they remained 2 to 3 times higher than those observed in the intact rats (Fig. 1, $E$ and $F$ ). Selenium deficiency did not affect serum TSH concentrations in the intact rats.

Effect of selenium deficiency on selenium content and 5'D-I activity in the thyroid. The failure of $\mathrm{T}_{4}$ replacement to normalize serum $T_{3}$ concentrations in the selenium-supplemented rats, despite the availability of normal $\mathrm{T}_{4}$ levels to the 5'D-I containing tissues, suggested that the thyroid gland may contribute up to $55 \%$ of the $T_{3}$ found in the circulation. Similarly, the thyroid appeared to contribute as much as $60 \%$ of the circulating $\mathrm{T}_{3}$ in the selenium-deficient rats, animals that lack the selenoprotein 5'D-I in the liver and kidney. Since earlier work suggested that intrathyroidal $T_{4}$ to $T_{3}$ conversion was a major contributor to the $T_{3}$ found in the dog thyroid effluent $(4,5)$,
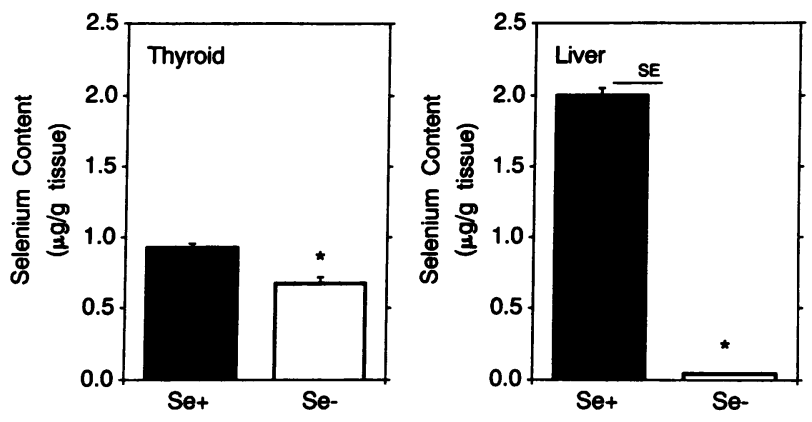

Figure 2. Effect of selenium deficiency on the selenium content in the thyroid and liver. Rats were fed a selenium-supplemented ( $\mathrm{Se}+$ ) or selenium-deficient $(\mathrm{Se}-$ ) diet for 5 wk then were killed. Selenium content was determined as described in Experimental procedures. ${ }^{*} P$ $<0.05$.

and thyroidal 5'D-I appears to be a selenoprotein (7), the near normal serum $T_{3}$ concentrations found in intact, selenium-deficient animals raised the possibility that thyroidal 5'D-I was unaffected by selenium deficiency. Thus, we determined the effects of selenium deficiency on thyroidal selenium content (Fig. 2) and on 5'D-I activity in the thyroid (Fig. 3). Rats fed the selenium-deficient diet had a $>97 \%$ fall in selenium content in the liver and a corresponding $>93 \%$ decrease in liver 5'D-I activity. However, in the thyroid, the selenium-deficient diet resulted in only a modest $27 \%$ decrease in selenium content, and paradoxically, the 5'D-I activity was increased by $25 \%$ $(P<0.05)$.

Effects of selenium deficiency on intrathyroidal metabolism of ${ }^{131} I$. To evaluate the influence of altered selenium intake on intrathyroidal iodine metabolism, we determined the effects of selenium deficiency on the thyroid gland's ability to concentrate and organify iodine. Thyroidal uptake of ${ }^{131} \mathrm{I}$ was unaffected by selenium intake, and there were no differences in the synthesis of the ${ }^{131}$ I-labeled iodotyrosines (MIT and DIT) or iodothyronines $\left(T_{4}\right.$ and $\left.T_{3}\right)$ between selenium-deficient and selenium-supplemented rats (Table I).

\section{Discussion}

Controversy surrounds the contribution of the various tissues to $T_{3}$ production in the rat. DiStefano (1) estimated that $47 \%$ of $\mathrm{T}_{3}$ originates from both thyroidal secretion and extrathyroidal $T_{4}$ to $T_{3}$ conversion in liver and kidney, while the remain-
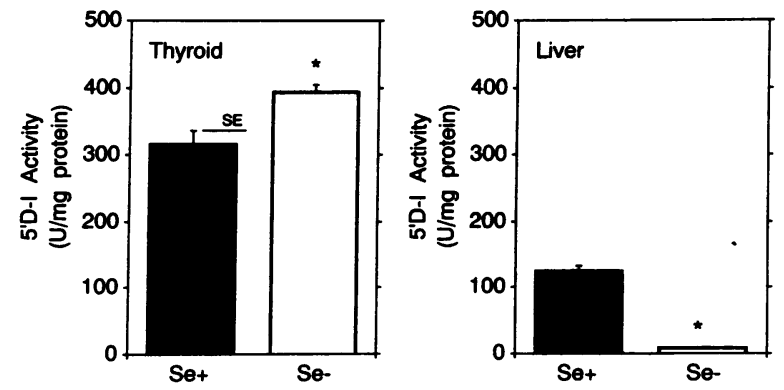

Figure 3. Effect of selenium deficiency on 5'D-I activity in the thyroid and liver. Rats were fed a selenium-supplemented $(\mathrm{Se}+)$ or selenium-deficient $(\mathrm{Se}-$ ) diet for $5 \mathrm{wk}$ then were killed. 5'D-I activity was assayed as described in Experimental procedures. ${ }^{*} P<0.05$. 
Table I. Effect of Selenium on Intrathyroidal ${ }^{131}$ I Metabolism

\begin{tabular}{lcc}
\hline & $\mathrm{Se}+$ & $\mathrm{Se}-$ \\
\hline \% Uptake & $9.4 \pm 1.3$ & $12.7 \pm 3.2$ \\
$\%$ MIT & $27.4 \pm 0.6$ & $27.0 \pm 2.2$ \\
$\%$ DIT & $41.4 \pm 1.6$ & $36.9 \pm 1.5$ \\
MIT/DIT & $0.74 \pm 0.08$ & $0.67 \pm 0.03$ \\
$\% \mathrm{~T}_{3}$ & $1.0 \pm 0.3$ & $1.1 \pm 0.2$ \\
$\% \mathrm{~T}_{4}$ & $4.1 \pm 0.5$ & $3.1 \pm 0.3$ \\
$\mathrm{~T}_{3} / \mathrm{T}_{4}$ & $0.33 \pm 0.06$ & $0.25 \pm 0.06$
\end{tabular}

Intrathyroidal metabolism of ${ }^{131} \mathrm{I}$ was determined in 5 selenium-supplemented $(\mathrm{Se}+)$ and 5 selenium-deficient $(\mathrm{Se}-)$ rats as described in Experimental procedures. Results are expressed as mean \pm SE.

ing 53\% comes from $T_{4}$ to $T_{3}$ conversion in the slowly equilibrating pools, such as brain, skin, and muscle. Kinlaw et al. (3) revised their earlier estimate that only $20 \%$ of $\mathrm{T}_{3}$ is produced by extrathyroidal $T_{4}$ to $T_{3}$ conversion in the rat (2) and suggested that essentially all $T_{3}$ is produced by $T_{4}$ to $T_{3}$ conversion. They also speculated that there is little or no direct secretion of $\mathrm{T}_{3}$ by the thyroid.

The current data demonstrate that at least $55 \%$ of circulating $T_{3}$ comes from the thyroid gland in the intact, seleniumsupplemented rat. Since liver and kidney 5'D-I still contribute to the pool of circulating $T_{3}$ in these rats, it is difficult to estimate the relative contribution of the thyroid to total body $\mathrm{T}_{3}$ concentrations. Moreover, the failure of $T_{4}$ replacement to normalize serum $T_{3}$ concentrations in thyroidectomized rats, resulting in reduced liver 5'D-I activity, further complicates the analysis of the sources of circulating $T_{3}$. However, in the selenium-deficient rat, liver and kidney 5 'D-I are virtually absent (12), and the contribution of the thyroid to the serum $T_{3}$ pool can be approximated. The contribution of thyroidal $T_{3}$ derived from thyroglobulin and that from thyroidal $T_{4}$ to $T_{3}$ conversion to the circulating $T_{3}$ pool in these animals, as estimated from the data presented in Fig. 1 panel $D$, is approximately $65 \%$ and the residual serum $T_{3}$ concentrations present in these rats lacking both the thyroid and extrathyroid 5'D-I is in excellent agreement with previously measured values (12). The source of the residual $\mathrm{T}_{3}$ in the serum of thyroidectomized rats with essentially undetectable serum $\mathrm{T}_{4}$ concentrations and no hepatic and renal 5'D-I remains unclear. Taken together, extrathyroidal $\mathrm{T}_{4}$ to $\mathrm{T}_{3}$ conversion contributes $20-25 \%$, and thyroidal $T_{4}$ to $T_{3}$ conversion and $T_{3}$ derived from thyroglobulin contributes $55-65 \%$ of the total body pool of $\mathrm{T}_{3}$. Thus, nearly all the circulating $T_{3}$ derived from $T_{4}$ appears to be produced by the selenoenzyme, 5 'D-I.

Thyroidectomy resulted in a marked increase in serum TSH concentrations in both selenium-supplemented and selenium-deficient rats despite the maintenance of serum $T_{4}$ concentrations identical to those observed in the respective intact groups. The presence of increased serum TSH concentrations, decreased serum $T_{3}$ concentrations, and normal or elevated serum $T_{4}$ concentrations indicates that circulating $T_{3}$ plays an important role in regulating TSH secretion (12, 20, 21). Previously, we found a modest increase in serum TSH concentrations (12) in selenium-deficient rats that was proportional to the fall in circulating $T_{3}$ suggesting that TSH levels may actu- ally be slightly elevated for some period during dietary restriction of selenium.

Dietary restriction of selenium intake had only a marginal effect on the selenium content and levels of the selenoenzyme 5'D-I in the thyroid gland. Thus, while there was a near complete loss in hepatic selenium content and 5'D-I activity, the thyroid preserves its selenium stores and 5'D-I activity was increased by $25 \%$ in selenium-deficient rats. This increase in thyroidal 5'D-I may be due to TSH mediated stimulation of 5'D-I activity $(22,23)$ resulting from small increases in circulating TSH that may occur in selenium-deficient rats. Thus, despite the loss of extrathyroidal $T_{4}$ to $T_{3}$ conversion, the thyroid retains the ability to catalyze the 5 'deiodination of $\mathrm{T}_{4}$.

Similar preservation of thyroidal selenium stores was recently observed in rats fed a selenium-deficient diet for two generations. Behne and co-workers have observed that the thyroid gland and brain exhibited the highest avidity for selenium (24). Arthur et al. (25) recently found that thyroidal GPx activity fell by $\sim 50 \%$ after 5 wk of selenium deficiency. Since the $25 \%$ increase in thyroidal 5'D-I occurred during this same time period in our studies, these data suggest that the thyroid is resistant to the effects of selenium deficiency and that thyroidal $5^{\prime} \mathrm{D}-\mathrm{I}$ is preserved over other selenoproteins in selenium-deficient animals. The thyroid is not unique in this regard since the testis and brain also preferentially preserve selenium over other organs (26).

In this study, intrathyroidal iodine metabolism was also unaffected by selenium deficiency, whereas inconsistent results have been reported on the effects of selenium deficiency on intrathyroidal metabolism by others. Goldstein et al. observed a decrease in $\mathrm{PB}^{131} \mathrm{I}$ after in vitro incubation of thyroid glands from selenium-deficient rats with ${ }^{131} \mathrm{I}$ (27). Arthur et al. (25) found a decrease in both $T_{4}$ and $T_{3}$ content in the thyroid gland from selenium-deficient rats, while Meinhold et al. (28) found no change in $T_{4}$ and $T_{3}$ content in the thyroid from rats fed a selenium-deficient diet. Taken together, these data suggest that secretion of de novo synthesized $\mathrm{T}_{3}$ is unaffected by selenium deficiency. It is generally assumed that $70-80 \%$ of the circulating $T_{3}$ concentrations $(29,30)$ is derived from $T_{4}$ to $T_{3}$ conversion in human and similar, albeit, more variable estimates have been made for the rat and that the liver, kidney, and thyroid contain nearly all the 5'D-I activity in the body $(6,30)$. Since extrathyroidal $5^{\prime} \mathrm{D}-\mathrm{I}$ contributes $10-25 \%$ of the $\mathrm{T}_{3}$ production (see above), then more than $50 \%$ of the $\mathrm{T}_{3}$ in the thyroidal effluent is likely to be derived from intrathyroidal $T_{4}$ to $T_{3}$ conversion of $T_{4}$ liberated from thyroglobulin.

The finding that the majority of $\mathrm{T}_{3}$ in the rat derives from the thyroid provides a potential explanation for the apparent discordance between the observed $K_{\mathrm{m}}$ of $5 \mathrm{D}$-I and the concentration of $T_{4}$ available to extrathyroidal tissues. In vitro estimates of the $K_{\mathrm{m}}$ for $\mathrm{T}_{4}$ for 5'D-I range between 0.5 and $1 \mu \mathrm{M}$ (6, 30 ), while the $T_{4}$ available to the tissues ("free hormone") is 3-4 orders of magnitude less, indicating that catalysis by 5'D-I in peripheral tissues is very inefficient. However, intracellular $\mathrm{T}_{4}$ levels in the thyroid would be expected to be much greater than those in the circulation, and the $K_{m}$ for $\mathrm{T}_{4}$ of ${ }^{\prime} \mathrm{D}-\mathrm{I}$ may reflect the substrate available in the thyroid rather than that in the circulation.

In conclusion, the current study demonstrates that the thyroid gland is a major source of circulating $T_{3}$ in rats, accounting for approximately $55 \%$ of total $\mathrm{T}_{3}$ production. The contri- 
bution of intrathyroidal $T_{4}$ to $T_{3}$ conversion to $T_{3}$ homeostasis appears to be important, but the exact contribution remains to be determined.

\section{Acknowledgments}

We thank J. S. Morris, V. L. Spate, and C. L. Reams from the University of Missouri Research Reactor, University of Missouri-Columbia, Columbia, MO, for determination of tissue selenium content.

J.-P. Chanoine is the recipient of a Public Health Service Fogarty International Research Fellowship ( 1 F05 TW04373-01 ) and Aspirant at the Fonds National de la Recherche Scientifique, Belgium. This work was supported by grants DK-38772, DK-18919, and DK-02005 from National Institute of Arthritis, Diabetes, and Digestive and Kidney Diseases, National Institutes of Health, Bethesda, MD, and by a grant from North Atlantic Treaty Organization.

\section{References}

1. DiStefano, J. J., M. Jang, T. K. Malone, and M. Broutman. 1982. Comprehensive kinetics of $\mathrm{T}_{3}$ production, distribution and metabolism in blood and tissue pools of the rat using optimized blood sampling protocols. Endocrinology. 110:198-213.

2. Schwartz, H. L., M. I. Surks, and J. H. Oppenheimer. 1971. Quantitation of extrathyroidal conversion of L-thyroxine to 3,5,3'-triiodo-L-thyronine in the rat. J. Clin. Invest. 50:1124-1130.

3. Kinlaw, W. B., H. L. Schwartz, and J. H. Oppenheimer. 1985. Decreased serum triiodothyronine in starving rats is due primarily to diminished thyroidal secretion of thyroxine. J. Clin. Invest. 75:1238-1285.

4. Laurberg, P. 1981. Iodothyronine secretion from perfused dog thyroid lobes after prolonged thyrotropin treatment in vivo. Endocrinology. 109:15601565.

5. Laurberg, P. 1978. Selective inhibition of the secretion of triiodothyronine from the perfused canine thyroid by propylthiouracil. Endocrinology. 103:900905.

6. Kohrle, J., R. Dieter Hesch, and J. L. Leonard. 1991. Intracellular pathways of iodothyronine metabolism. In Werner and Ingbar's The Thyroid. L. E. Braverman and R. D. Utiger, editors. J. B. Lippincott Co., Philadelphia, PA. 144-189.

7. Berry, M. J., L. Banu, and P. R. Larsen. 1991. Type I iodothyronine deiodinase is a selenium containing enzyme. Nature (Lond.). 349:438-440.

8. Arthur, J. R., F. Nicol, and G. J. Beckett. 1990. Hepatic iodothyronine 5' deiodinase. The role of selenium. Biochem. J. 272:537-540.

9. Behne, D., A. Kyriakopolous, H. Meinhold, and J. Köhrle. 1990. Identification of type I iodothyronine 5'-deiodinase as a selenoenzyme. Biochem. Biophys. Res. Commun. 173:1143-1149.

10. Beckett, G. J., D. A. MacDougall, F. Nicol, and J. R. Arthur. 1989. Inhibition of type I and type II iodothyronine deiodinase activity in rat liver, kidney and brain produced by selenium deficiency. Biochem. J. 259:887-892.

11. Safran, M., A. P. Farwell, and J. L. Leonard. 1991. Evidence that type II 5 deiodinase is not a selenoprotein. J. Biol. Chem. 266:13477-13480.

12. Chanoine, J. P., M. Safran, A. P. Farwell, P. Tranter, D. Ekenbarger, S. Dubord, S. Alex, J. R. Arthur, G. J. Beckett, L. E. Braverman, and J. L. Leonard. 1992. Selenium deficiency and type II 5'-deiodinase regulation in the euthyroid and hypothyroid rat: evidence of a direct effect of thyroxine. Endocrinology. 131:479-484.

13. Beckett, G. J., S. E. Beddows, P. C. Morrice, F. Nicol, and J. R. Arthur. 1987. Inhibition of hepatic deiodination of thyroxine is caused by selenium deficiency in rats. Biochem. J. 248:443-447.

14. Chanoine, J. P., M. Safran, A. P. Farwell, S. Dubord, S. Alex, S. Stone, J. R. Arthur, L. E. Braverman, and J. L. Leonard. 1992. Effects of selenium deficiency on thyroid hormone economy in the rat. Endocrinology. 131:17871792.

15. Chada, S., C. Whitney, and P. Newburger. 1989. Post-transcriptional regulation of glutathione peroxidase gene expression by selenium in the HL-60 human myeloid cell line. Blood. 74:2535-2541.

16. Leonard, J. L., and I. N. Rosenberg. 1980. Thyroxine 5'-deiodinase from rat kidney: substrate specificity and the 5'-deiodination of reverse triiodothyronine. Endocrinology. 107:1376-1383.

17. Morris, J. S., M. J. Stampfer, and W. Willett. 1983. Dietary selenium in humans: toenails as an indicator. Biol. Trace Elem. Res. 5:529-537.

18. Bradford, M. M. 1976. A rapid and sensitive method for the quantitation of microgram quantities of protein utilizing the principle of protein-dye binding. Anal. Biochem. 72:248-254.

19. Vagenakis, A. G., S. H. Ingbar, and L. E. Braverman. 1974. The relationship between thyroglobulin synthesis and intrathyroidal iodine metabolism as indicated by the effects of cycloheximide in the rat. Endocrinology. 94:16691680.

20. Abend, S. L., S. L. Fang, S. Alex, L. E. Braverman, and J. L. Leonard. 1991. Rapid alteration in circulating free thyroxine modulates pituitary 5 ' deiodinase and basal thyrotropin secretion in the rat. J. Clin. Invest. 88:898-903.

21. Emerson, C. H., R. Lew, L. E. Braverman, and W. J. DeVito. 1989. Serum thyrotropin concentrations are more highly correlated with serum triiodothyronine concentrations than with serum thyroxine concentrations in thyroid hormone-infused thyroidectomized rats. Endocrinology. 124:2415-2418.

22. Wu, S. Y. 1983. Thyrotropin-mediated induction of thyroidal iodothyronine monodeiodinases in the dog. Endocrinology. 112:417-424.

23. Erickson, V. J., R. R. Cavalieri, and L. L. Rosenberg. 1982. Thyroxine 5 '-deiodinase of rat thyroid, but not that of liver, is dependent on thyrotropin. Endocrinology. 111:434-440.

24. Meinhold, H., U. Haselbach, B. Zegenhagen, A. Kyriakopoulos, and D. Behne. 1992. Effects of selenium deficiency and graded selenium supply on type I 5 ' deiodinase and glutathione peroxidase activities in various rat tissues. J. Endocrinol. Invest. 15(Suppl. 2):131. (Abstr.)

25. Arthur, J. R., F. Nicol, P. W. Rae, and G. J. Beckett. 1990. Effects of selenium deficiency on the thyroid gland and on plasma and pituitary thyrotrophin and growth hormone concentrations in the rat. Clin. Chem. Enzym. Comms. 3:209-214.

26. Behne, D., H. Hilmert, S. Scheid, H. Gessner, and W. Elger. 1988. Evidence for specific selenium target tissues and new biologically important selenoproteins. Biochim. Biophys. Acta. 966:12-21.

27. Goldstein, J., B. Corvilain, F. Lamy, D. Paquer, and J. E. Dumont. 1988. Effects of a selenium deficient diet on thyroid function of normal and perchlorate treated rats. Acta Endocrinol. 118:495-502.

28. Meinhold, H., A. Campos-Barros, and D. Behne. 1992. Effects of iodine deficiency on iodothyronine deiodinases in brain, thyroid and peripheral tissue. Acta Med. Austriaca. 19(Suppl. 1):8-12.

29. DeGroot, L. J., P. R. Larsen, S. Refetoff, and J. B. Stanbury. 1984. Hormone synthesis, secretion, and action. In The Thyroid and Its Diseases. 5th ed. John Wiley \& Sons, New York, NY. 36-117.

30. Leonard, J. L. Identification and structure analysis of iodothyronine deiodinases. 1990. In The Thyroid Gland. M. A. Greer, editor. Raven Press, New York. 285-305. 